\title{
THE MAKING OF A BISHOP: PERSONAL REFLECTIONS BY A COMPANION ALONG THE WAY
}

\section{Ernst-August Lüdemann}

Evangelical Lutheran Mission in Lower Saxony, Germany

e.a.luedemann@web.de

\section{ABSTRACT}

With this text a German missionary, originating from the Lutheran Hermannsburg Mission, describes his way of service in southern Africa through which he is getting ever closer to Dr Manas Buthelezi. From the outset of Lüdemann's ministry in KwaZulu-Natal he got to know the young but already widely acclaimed theologian (Buthelezi) in the same diocese. The intensive involvement of Buthelezi in the Black Consciousness Movement gave Lüdemann a deeper insight into his own challenges in apartheid South Africa, and at the same time he understood the critical position in which he had to see himself as a foreigner from Europe.

Buthelezi - through various positions in his own Lutheran Church (Bishop of ELCSA-Central Diocese, Lutheran World Federation) and in the ecumenical context (Christian Institute, South African Council of Churches) - deepened his theological expression in view of the endangered society, and at the same time formulated the specific prophetic message of a relevant Christian gospel. This meant that he was severely challenged in conflicts between various interest groups. More and more he realised that he could with his ministry only survive through a clear scripture-related spirituality as part of the work of the Holy Spirit.

Keywords: South African church history; Dr Manas Buthelezi; Lutheran Church

\section{STATIONS OF COMPANIONSHIP}

Intending to write about personal reflections in relation to the retired and now late Bishop Dr Manas Buthelezi, I have to start indicating under which conditions and circumstances we met and arrived to a certain extent at similar theological emphases

\section{UNISA $\cong$}

Studia Historiae Ecclesiasticae Volume 42 | Number 1 | 2016 pp. 142-158
DOI: http://dx.doi.org/10.17159/2412-4265/2016/513 Print ISSN 1017-0499 | Online 2412-4265 (C) 2016. Studia Historiae Ecclesiasticae 
during our work in the Lutheran Church in South Africa. I arrived in Durban/ KwaZulu-Natal in 1967 as a missionary co-worker of the Hermannsburg Mission (now Evangelical Lutheran Mission of Lower Saxony/Germany [ELM]). At that time I was called and placed by the Cooperating Lutheran Missions in Natal (CLM) with the task of congregation building in the Indian community of greater Durban. This was my commitment for the following 15 years. In 1968 Buthelezi arrived back in South Africa after having completed his doctoral studies in the USA. I got to know him from the time when he began his parish ministry in Sobantu/Pietermaritzburg. Now I met and heard him at various occasions within the same diocese (Evangelical Lutheran Church in Southern Africa/ELCSA-South Eastern Diocese) in which also the Lutheran Indian Parishes exist.

During the next major period in Buthelezi's life and ministry from 1973 to 1977 we met at occasions when he delivered lectures in his functions as Natal Director of the Christian Institute, as Secretary General of the Federation of Evangelical Lutheran Churches in Southern Africa (FELCSA) and as executive member and later President of the South African Council of Churches (SACC).

In 1977 Buthelezi was elected as the bishop of the newly created Central Diocese (Johannesburg) of ELCSA. In 1982 I was appointed as Senior for the ELM and its work and co-workers in five southern African countries. For this position I had to move to Pretoria and became at the same time co-worker in the ELCSA-Central Diocese. This was the period in which I had the closest contact and cooperation with Bishop Buthelezi. At various occasions like regular workers' meetings, retreats and diocesan synods, I appreciated his clear guidance at a time when the church was heavily challenged by the political turmoils of the country. But I also saw it as my task as a Senior to evaluate and reshape the services of ELM co-workers in the diocese together with Bishop Buthelezi, or at other occasions to enter into theological discussion with him concerning the developments within the ministry of the Lutheran Church in the country and her spiritual outreach. This was a time in which our mutual trust and understanding was really deepened.

In 1988 I was called back to Germany to take over the directorship of the mission (ELM). This reduced my possibility of meeting Bishop Buthelezi, but it never severed our relationship. During my regular official visits to South Africa we made a point of meeting, but also continued our correspondence. For me this relationship has really enriched my experiences of South Africa and helped me towards a deeper understanding of this country with so many differences and also controversies under the aspects of culture, religiosity and developments of society. Most of all I realised how a person like Bishop Buthelezi developed in his spirituality under the increasing challenges on his life in the South Africa of apartheid. 


\section{CHALLENGE OF BLACK CONSCIOUSNESS}

In 1968 Buthelezi returned from his doctoral studies in the United States of America (Drew University). There he had come across the newly emerging movements of black consciousness and black theology. ${ }^{1}$ As he was teaching now at the Lutheran Theological College (LTC) at Umphumulo from 1969 to 1970, he got into contact with certain people who represented these initiatives in South Africa like Stanley Ntwasa and Basil Moore of the University Christian Movement. In the USA he had sensed the strong impact of this way of thinking among the Afro-American community leaders and students; and now he wrote about the situation after his return to South Africa:

Since these movements had originated in the USA where I had studied, I could sense that something was expected of me...There was a symbiotic relationship between me and these organizations, since at every turn and every speaking invitation I received, I felt challenged to demonstrate in a convincing manner the relevance of the Christian Gospel to the black person who was daily oppressed, simply because of his/her blackness. I found this level of expectation, on the part of the young black intellectuals, very thrilling...For me at last theology and black political reflection had mutually discovered a common meaning and destiny. 2

Buthelezi felt at home in the movement of young black people eager like himself to find a place of equal respect and appreciation in the context of a society of discrimination. The Black Consciousness Movement tried to be rather inclusive and attracted people of various walks of life, ethnic and religious backgrounds. Through the youth work I did in Durban I came into contact with young Indian students who were instrumental in building up SASO (South African Students' Organisation) which was a core movement to spread the idea of black consciousness. Among them I met people like Sats Cooper and Strini Moodley ${ }^{3}$ who often told me about the valuable contributions of a theological thinker like Buthelezi. But the real playing field, for Buthelezi, was his theological reflection on black theology. In southern Africa he became a leading figure, not only within the framework of Lutheran theology. In 1972 he contributed a lecture for the Missiological Institute of the LTC Umphumulo, with the title African theology and black theology: A search for a theological method. ${ }^{4}$ Here he pointed to the misunderstandings of black theology as a campaign of political nature. He differentiated his theological choice over against an African theology which he saw more as a kind of romantic element in the missionary movement, and which tried to open up traditional religious elements of Africa towards a baptism by elements of the

1 Cf. James H. Cone, Black theology and black power, New York 1969

2 M. Buthelezi, Profile of sociopolitical involvement, Ezidwadweni 2010, p. 1.

3 Both of them were later sentenced to longer terms in prison; S. Moodley for six years on Robben Island.

4 Buthelezi in H.J. Becken (ed.), Relevant theology for Africa, Mapumulo 1973, pp.18-24. 
gospel. All this he saw as being too superficial, as it still left the African person in an inferior position. His vision was:

The black theology methodology takes seriously the situation of the black man and seeks to understand the gospel in relation to experience in this situation. Seeing that the black man experiences life from the position of being rejected because of his blackness, the methodology seeks to interpret the gospel as a liberating event from the chains of rejection. The chains from which the black man has to be liberated are the myths concerning what it means to be black and the life patterns which militate against the spirit of the gospel. ${ }^{5}$

With this theological approach Buthelezi overtook the traditional theological trends held in the earlier missionary circles through which, however, the foundations of his church were laid in South Africa since the 1830s. In 1972 he was invited to be a visiting professor at the University of Heidelberg (Germany). Sharing his theological understanding within the context of black consciousness in southern Africa he raised a strong interest on a far broader theological spectrum in Europe, where many high school academics were fairly unable or unwilling to involve themselves in the traditional mission movements of their churches abroad. Now many of them became interested and involved in a new movement of partnerships between regional German church circuits and equivalent units in South Africa. In the long run this brought about a much broader involvement of Christians in Germany with the partner churches in the south and opened up a much wider spectrum of topics of Christian witness in foreign societies.

However, this included also a rather critical assessment of Buthelezi and his theological friends in South Africa over against the traditional missionary movement. They could express themselves in the harsh statement: 'Missionary, go home and leave the black man; he is mature enough to manage his own affairs'. ${ }^{6}$ This was most upsetting for us young missionaries, but nevertheless I could develop a growing trustful relationship with Buthelezi so that I understood the deeper truth and necessity of such a statement. It was an ambiguous experience that he had made in relation to foreign missionaries in his land. He once told me about research he had done in Uppsala, Sweden, in the archives of the Church of Sweden Mission (CSM). He found the reports of Swedish missionaries in Zululand who had reported home about their first encounters with Zulu people, their backward culture and their distorted religion. That was a time when language studies were inadequate and when the philosophy in Europe looked down upon the tribal life in Africa, which needed wholesale development from the side of Europeans. Naturally, Buthelezi knew that these reports had been written 60 and more years ago and that the Second World War had turned the world around. However, he realised that this type of thinking had not

5 Buthelezi in H.J. Becken (ed.), Relevant theology for Africa, Mapumulo 1973, pp. 23-24.

6 J. Mashabela, Manas Buthelezi. Dictionary of African Christian Biography. http://www.dacb.org/ stories/southafrica/buthelezi_manas.html 
at all been overcome in present times in South Africa and even not in certain church circles. For a new and ecumenical partnership between the north and the south a new kind of thinking and realisation of oneness was necessary.

On the other hand, Buthelezi could speak with great admiration of the missionary endeavours in his home area in central Zululand. His own father, Absalom Buthelezi, worked as an evangelist together with Swedish missionaries and their joint work made a tremendous impact in an area of Zululand where not only the loyalty to the Royal House of the Zulu kings was strongly upheld, but also the religious adherence to living together with the ancestral spirits. In the midst of all this, Absalom Buthelezi was a convinced and ardent messenger of the living Christ. Sharing in all these experiences was a great blessing for us as young foreign missionaries struggling to develop meaningful work in the midst of a society under the suppression by white racism. But the fortunate element with Manas Buthelezi was that he understood himself as a theologian, personally adhering to Christ as his Lord and responsible over against the Word of God, and not locked up within an ideology, even not a black one.

In this respect I only learned years later, in a personal conversation with him, what might have been the deeper root of his Christian awareness. After his first school years in the 1940s in the area of Mahlabatini/KwaZulu-Natal he continued his education at St. Francis Mariannhill, a Roman Catholic institution, where he matriculated and where he also completed his teachers' training programme. Besides the solid basic education he also gathered in the monastic context a deep insight into the spiritual life of a Christian community - in the fellowship of many black young people. He related to me how on one day a stained glass window with a biblical theme, and illuminated by the sun falling through, touched him so deeply that he early in his student life realised the presence of the living God - far beyond any European monastery structures or traditional Zulu beliefs. So - as he put it - the Spirit of the Holy God of Jesus Christ had deeply approached him. These were the early roots of the later decision - after a few years as a schoolteacher - to enter the ministry of the church, and that this was more than a profession, it was a calling.

\section{PROPHETIC MINISTRY IN A DIVERSE RELIGIOUS AND SECULAR CONTEXT}

In 1972 the ambit of Buthelezi's activities, still understood as his church ministry, was considerably widened when he was called to serve as Natal Regional Director of the Christian Institute, an ecumenical organisation critical of the government policies which were seen as 'exposing the unchristian doings of the white minority regime'? The ELCSA, Buthelezi's home-church, released him for this special service. He

7 J. Mashabela, Dictionary of African Christian biography, p. 1. 
understood himself as being particularly fortunate as working very closely now with the (former) Dutch-Reformed minister, Beyers-Naudé. Despite a dramatic personal way out of the midst of (white) Afrikanerdom he held in his heart and mind two things together - a deep relationship to God and his holy Word and so also to his home-church which had rejected him, and on the other hand a deep commitment towards the liberation of the black and other discriminated peoples in their common homeland South Africa. Buthelezi wrote about this relationship: 'Of all the people I met in my life, it is Beyers-Naudé who gave me what I would call political baptism and a formal political platform. ${ }^{8}$ What followed was an immense programme of addressing political, community, teachers, church, university and general school audiences. Furthermore he could write in the central publication of the Christian Institute, Pro Veritate. From this special position Buthelezi could play a vital role in advocating for thousands of voiceless South Africans. This, however, was realised by the government when in December 1973 Buthelezi was placed under a ban in terms of the Suppression of Communism Act. This happened shortly after the banning of the SASO leaders, including Steve Biko of the Black Consciousness Movement. The government had understood that these organisations were not just something for the blacks to debate their own problems (which could still have been tolerated under the 'Separate Development Policy'), but that hereby a deep mental change was developing among the discriminated people pressing for an overall rearrangement of the society for equal citizenship. Buthelezi wrote himself about the execution of banning:

After reading the text of the banning order the Security Police asked whether I had any question. I told them that I felt I should first ask God in prayer what His will is for me from then on. After finishing the prayer I proclaimed to them: "God is going to reveal Himself." They seemed to be startled and inquisitive when asking, as if with wide open eyes: "What is going to happen?" I readily answered: "In Matthew 28 Jesus said 'I shall be with you until the end of age"'. Although the Security Police verbally said to me "No more preaching", the written banning order itself only prohibited me for five years from attending political, social and student gatherings, and alleged that I was promoting the aims of Communism. ${ }^{9}$

However, because of the worldwide protests the banning order was lifted already after six months instead of five years.

In 1974 his church called him to take over the position of General Secretary of the Federation of Evangelical Lutheran Churches in Southern Africa (FELCSA), but he also contributed on a worldwide scale after he had been co-opted into the leadership of the Lutheran World Federation (LWF/Geneva) as well as special study committees of the World Council of Churches (WCC/Geneva) and the All Africa Council of Churches (AACC/Nairobi). All over he was trusted because of his

8 M. Buthelezi, Profile of sociopolitical involvement, 2010, p. 1.

9 M. Buthelezi, Profile of sociopolitical involvement, 2010, p. 2. 
theological sincerity and spiritual emphasis as well as his openness in representing the South African dilemma and his involvement in challenges of the society.

With his appointment for FELCSA Buthelezi - as especially in 1976 with the election as the General Secretary of ELCSA - had to shift his residence to Johannesburg. This put him at the centre of a whirlwind of political events. He was still available for support to the Black Consciousness Movement in which Steve Biko had played the role of a politico-philosophical leader, and he himself with the strong backing of the churches translated the community issues into theological language - the 'Black Theology of Liberation'. On 16 June 1976 the catastrophe broke loose with thousands of students protesting in Soweto against their life being under suppression of various kinds. This was answered by the security forces with an all-out severe reprisal. More than 570 protesters were killed during this day and the following connected riots. For Buthelezi and other responsible people in the black community, this meant a tremendous task of empathic control of the incensed students and endless contacts of intervention with police and government offices. On 21 June 1976 an urgent meeting took place in the Methodist Youth Centre in Soweto, bringing together clergymen, social workers, medical doctors and leading sports organisers to determine what should be done after the catastrophe of the riots. The result was the establishment of the 'Black Parents' Association' (BPA) which had as its main tasks:

To explore and implement constructive ways of standing in solidarity with the black protesting students. To help in identifying hundreds of dead students who were shot by the police, and also to identify and support the respective bereaved families. To establish a fund... 10

All this was communicated to the Johannesburg magistrate. Buthelezi was elected the chairman of the BPA, a very stressful and exhaustive task. Many a times he had to meet with the Minister of Police as well as the Deputy Minister of Bantu Education. Relatively small achievements could be worked out like e.g. the founding of the 'Committee of Ten' under Dr N. Motlana, which gave rise to increased establishment of many civic associations for taking over local responsibilities.

Buthelezi described this period for the rescue of life in the black community as extremely burdening with the following words:

I did not personally have a taste and inner calling for being a professional politician. As a clergyman I believed that my role in the community was what we call in the church prophetic ministry. A prophetic ministry includes identifying problems and needs in the community, challenging governmental bodies to attend to those needs, and facilitating a process or processes which will harness and employ the leadership gifts of local people towards selfhelp and self-management towards the goal of meeting those needs. Our duty as a church or official church functionaries is to help in building and developing the leadership potential of

10 M. Buthelezi, Profile of sociopolitical involvement, 2010, p. 3. 
the people in the community and not to replace by intent the people with ourselves... what was achieved in the context of the Soweto uprising...is found one example of the practical workings of what is called the prophetic ministry of the church. ${ }^{11}$

Here we understand once more that the personal Christian calling of Buthelezi remained under extreme pressures from the side of the society in conflict with the basic movens of his thinking and his decisions. This even included far-reaching decisions for his closest family. ${ }^{12}$ He turned down one and the other invitation by friends in foreign countries offering him lucrative positions and safe-life circumstances for his family:

These days I sometimes get tempted by imagining what would have happened to the life of my children if I had decided to make use of all those offers. That thought never occurred to me then. Every major decision in life has ripples of effects to those nearest to you, either positively and negatively. There is a line in a hymn which says: "Once in every man and nation comes a moment to decide.” That was my vital moment to decide. ${ }^{13}$

\section{THE BISHOP TOSSED ABOUT BETWEEN DIFFERENT LINES OF INTEREST}

In 1977 Buthelezi was elected as the first bishop of the newly created ELCSACentral Diocese, an office which he took over at the age of 42 and continued for more than 20 years. Especially in the first years of the new office his involvement in the socio-political scene was still rather strong. Mainly this arose in connection with the South African Council of Churches (SACC) in which he served first in various committees and then as president from 1983 to 1990. The expectations towards him were still rather strong from the side of suppressed black community movements. Still he was often seen - besides his main professional role as a bishop - visiting townships which were under special stress and attack by the security forces. He was leading SACC delegations to negotiate with government ministers or police officers. The SACC was after the banning of the BPA and the Christian Institute in 1977 the only organisation still allowed to operate although under continuous scrutiny by the security officers. This reached a certain peak in the physical attack on the building housing the SACC administration, namely Khotso House in Johannesburg. Buthelezi found particular support for his stand through the able administration of John Rees of the Methodist Church as General Secretary, and later Archbishop Desmond Tutu as well as Wolfram Kistner with his challenging theological input. After Buthelezi had completed his first term as president he was urged to continue for another term as tensions within the leadership of the SACC erupted between those

11 M. Buthelezi, Profile of sociopolitical involvement, 2010, p. 5.

12 Including his wife Grace, née Mhlungu, and four children, two girls and two boys.

13 M. Buthelezi, Profile of sociopolitical involvement, 2010, p. 3. 
who wanted to break any negotiations with the government since they regarded its policy as finally unchangeable (status confessionis), and those who felt that their continued role would be that of appealing for justice and reconciliation and through bridge building even under continued suffering. The bishop found the necessary trust to keep the council together through his convincing theological reasoning and enduring spirituality. He held on to his principle for the engagement between the lines: 'It is part of our job description as clergymen to mend fences where they are broken. ${ }^{14}$ Part of this commitment was that the bishop kept the diocesan centre in the midst of Soweto open for community events primarily of the black society. I have experienced at various occasions of church and community affairs how helpful the calm atmosphere of this centre was in the midst of the large suburban town full of fear and uncertainty. Later, after the unbanning of primarily black national antiapartheid organisations. the first formal ANC meeting on South African soil was held at this Lutheran diocesan centre. In the final years of his presidency Buthelezi could, through his involvement with overseas bodies like the LWF and the WCC, take part in meetings with representatives of the liberation movements in exile like the ANC and PAC. Also on that side it was not easy to build up trust over against the prophetic role of the SACC, but at least they talked to each other and later appreciated each other's roles with building up the new South Africa. Buthelezi completed his period as SACC president up to the unbanning of the ANC, PAC and Communist Party, and up to the preparations for the release of Nelson Mandela from Robben Island. ${ }^{15}$

On 10 May 1994 Nelson Mandela was inaugurated as the first black president democratically chosen by an electorate comprising all people of the country. This was the time when Buthelezi and other theologians felt that they had done their job in filling the political vacuum as spiritual leaders in the political arena. ${ }^{16}$ Now he could entirely devote himself to the commission as a bishop, which he had already held since 1977 and which had put him in charge over the rather diverse and conflictridden area of Greater Johannesburg. Also, from this aspect he felt the need for mending the torn fabric of the society as it presented itself within his parishes and congregations. Inside the church there were the obvious rifts caused by different political convictions (e.g. black-on-black violence) as well as the experiences of suffering and loss of life. There was a young generation which was restless in fighting for change, also demanding changes in the structures of the church and the role of its officers. After 1994 Buthelezi shifted his emphasis from a political liberation theology to an emphasis on implications of the Lutheran teachings of 'sola Scripture, sola fide, solus Christus and sola gratia.${ }^{17}$ However, this did not mean

14 M. Buthelezi, Profile of sociopolitical involvement, 2010, p. 8.

15 M. Buthelezi, Profile of sociopolitical involvement, 2010, p. 6.

16 J.Mashabela, Dictionary of African Christian biography, p. 2.

17 J.Mashabela, Dictionary of African Christian biography, p. 3. 
that he withdrew from the earlier emphases, but it had been God's calling for him at a certain given time in his life and world.

Besides the tremendous amount of tasks and topics which filled the daily routine of the bishop there were certain fields in which he increasingly saw his specific commitment for the regeneration of church life from the local congregation to the worldwide fellowship of the LWF.

\section{REVIVAL OF SPIRITUAL LIFE IN THE CONGREGATION.}

Very soon after he could concentrate on the internal life of his diocese Bishop Buthelezi made it a regular practice to conduct mission weeks in the various circuits of his area of responsibility. This task he also propagated very strongly in the diocesan workers' conferences where I met him from time to time. He also arranged for retreats in the dioceses centre, which were meant for the full-time pastors to deepen their spiritual life for witnessing and pastoral care in the congregations. In the congregations and particularly among the lay leadership this emphasis of the bishop was very well received. Many of them were young intellectuals with great interest in church life, who were grateful to be able to express their faith in the context of modern urban life and its particular challenges. They often came from the background of rural congregations with a solid piety from missionary times. This needed to be reshaped into a more modern way of thinking and living, and still based on daily practice of prayer and Scripture reading. In connection with personal challenges, room was given to forms of blessing and laying on of hands. The bishop even continued during the time of his retirement - as invited - with the revival conferences and Bible study weeks as 'people are thirsty for meaning and direction in their life of faith'. ${ }^{18}$

\section{NEW CLARITY WITH REGARD TO THE OFFICE OF THE ORDAINED MINISTER}

Through the many unsettling changes in the life of the church on the one hand, especially through the fast urbanisation of her work, but even more through the tense developments in the society asking for change, also the role of the pastor was affected by uncertainties and demands for new structures.

There was a new generation of pastors who had received - especially through their degree qualifications obtained at the University of KwaZulu-Natal in Pietermaritzburg - a new acknowledgement in the new South Africa in a much wider field of the society with good employment opportunities. However, they were not at all interested in severing their role within the church and even offered their

18 Letter to E-A. Lüdemann, 30 June 2010. 
further services free of charge - now under the title of 'self-supporting ministers'. With the employment experiences from outside the ambit of the church they brought a lot of ideas and proposals concerning workers' laws including arrangements for a 'workers' representation' (Clergy trade unionism). This arrangement, first of all, found a lot of interest in most of the dioceses as there were increasing numbers of vacancies of pastoral positions. In many cases those persons who opted for the self-supporting ministry were very able in their theological foundation and their means of communication. Bishop Buthelezi, however, saw a basic danger in this development with regard to the unity of the church and her pastoral ministry. On the background of his understanding of the pastoral office in the Lutheran Church he could only see the way of a layperson after some time of sound involvement in parish work and a thorough theological training towards an ordained ministry for a part-time service. For him the relevant term of the pastor's ministry was not the general 'church worker', but from its content the 'servant of God'. The bishop fought for clarity in this respect among the pastors and deans in his diocese. This, however, led to quite some estrangements over against certain groups of his clergy. Some of them had organised themselves within a co-workers' action group called LUMASA (Lutheran Ministers' Association of South Africa). Starting from the Central Diocese the controversy spread in time over the whole of ELCSA so that this became the key topic for a General Assembly of the Church at the end of 2010 for which Bishop Buthelezi - in the meantime for several years in retirement - was asked for the principle lecture with the title 'The ordained ministry in the historical and ecumenical Context'. ${ }^{19}$. In this very thorough study document he starts off from the biblical and the ecumenical aspects of the understanding of the central and fundamental office in the church for which a basic bond is established through the ordination between a specifically called individual and the sending Spirit of God. Although there are various commissions for services in the church, Buthelezi states for the specific ordained ministry:

ELCSA has no authority to interfere in God's act to call a pastor by way of seeming to have power to authorise a pastor to move from fulltime ministry in the church to fulltime ministry outside the church if that was not implied in his/her ordination vow. ${ }^{20}$

This rather definite understanding is one of the legacies the Bishop Buthelezi left behind for ELCSA, which still is grappling to find a clear understanding of the ministry. This should not break the church into various interest groups of leadership and workers' affairs, but which on the other hand should give the individual pastor

19 M. Buthelezi, General Assembly key-note: The ordained ministry in the historical and ecumenical context, Johannesburg 2010.

20 M. Buthelezi, General Assembly key-note: The ordained ministry in the historical and ecumenical context, Johannesburg 2010, p. 18. 
the full spiritual authority under the authorisation by the Holy Spirit of God and in full trust within the 'communio fratrum' (fraternal communion in the church).

\section{THEOLOGICAL TRAINING AND SPIRITUALITY}

Buthelezi had during his earlier years in the ministry been a lecturer at the LTC of Umphumulo (1969-1970), and after various other theological experiences it was one of his tasks as the bishop of the Central Diocese to be member of the board of the LTC. From that time on and afterwards in connection with the Theological Faculty at the University in Pietermaritzburg, he increasingly raised the question of the competence for theological teaching of future ministers in the Lutheran Church in southern Africa. In general he did not doubt the academic efforts of the teaching staff, but through his experiences with the diocesan clergy he realised that one aspect was underrepresented during the time of training - the personal spiritual practice. One example may be quoted from his General Assembly lecture on the ordained ministry where he refers to the prayer life of pastors:

What is prayer then in this context? It is by no means just a mechanical and verbal struggle of moving and changing an unwilling God, but a spiritual act of stretching forth one's receiving hands of faith through the chasm of human unbelief and self-trust...It is important to remember this particularly when we have to pray around an issue repeatedly before the answer materializes. The act of repetitive praying on our side is an exercise of faith in a God who is ever willing to give us what we ask for. The problem may have been that the receiving and trusting hands of faith were not yet stretched far or properly enough. ${ }^{21}$

Was there a proper balance in the shaping of future ministers between the academic acquiring of theological knowledge and the growth in spirituality? For all students there was a bulk of knowledge to be learnt and to be tested on in exams. But what about personal prayer and Scripture reading and meditation? What about communal spiritual life which did not only exist in the liturgically well arranged devotions but also in 'mutuum colloquium et consolatio fratrum'(M. Luther: Mutual fraternal conversation and consolation)? At this point considerable trust and understanding developed between the bishop and pastors who had been trained in the Mission Seminary of Hermannsburg, Germany then in the service of ELCSA. With him insisting on a more holistic understanding of pastors' training he did not only want to point to a South African dilemma. He had visited churches in the north in connection with his engagement as visiting theological professor and he had realised that a similar problem existed in Germany and Scandinavia. The theoretical training was often far removed from the scene in the congregations where people are in need of spiritual guidance and pastoral counselling. We were very much of one mind

21 M. Buthelezi, General Assembly key-note: The ordained ministry in the historical andecumenical context, Johannesburg 2010, p. 22. 
when I spoke to him about the concept of missionary training at the seminary of Hermannsburg during my studies there. As from the early 60s a new concept of training had been introduced in the seminary which emphasised this balance. ${ }^{22}$ As the result one realised that the future missionaries who had gone through this holistic training concept were well equipped for an integrated service in the partner churches. Important elements were the intensive language studies, attempting to cope with local theological challenges as well as finding relationships of trust in faith and prayer with the people in the congregations.

The faith in Christ is not the result but the precondition for such studies...Our principle is that the Holy Scripture itself offers us the understanding that Christ is the centre of the biblical message through whom all the individual expressions, events and informations in biblical texts start making sense for us. ${ }^{23}$

The historical-critical analysis of biblical texts is a useful tool with regard to their coming about in space and time, but above all that stands that they contain the Word of the Holy and living God who wants to use it to give our life a clear pattern, a living expression, according to his will (in German: 'Gestalt').

\section{THE COMMUNION-CHALLENGE FOR THE LUTHERAN WORLD FEDERATION}

A further expression of Buthelezi's efforts to spiritually deepen the understanding of the church in her global expression, was his involvement in renaming the Lutheran World Federation.

For many decades the LWF has understood itself as merely a free association of churches. A structure of free association was understood to leave in tact the autonomy and integrity of the member churches...The problem that surfaced was how to couch the free association concept in theological terms...Did the Lutheran World Federation have a church character or not? ${ }^{24}$

Buthelezi joined the efforts towards the use of the term 'Communion'. This was not a new theological concept. The Apostle Paul makes repeated use (13 times) of the Greek term 'Koinonia' when describing the evolving young church with all her differences and tensions and needs for one spiritual expression and unity. Out of such reality Buthelezi saw the life of the LWF as in need of God's gift of healing.

It is God's healing gift, not only in the sense that life in communion comes with the gift of salvation, but also because this old, biblical term has all of a sudden come as a fresh tool of

22 O. Hanssen, Theologiestudium in der Krise, Hermannsburg 1969.

23 Hanssen, ibid, p. 21 (translated by author).

24 M. Buthelezi, God's healing gift of Communion, Ezidwadweni 2003, p. 1. 
helping Lutheran churches to understand who they are jointly and severally. The concept cannot be credited to human creativity. ${ }^{25}$

Buthelezi saw - in connection with the LWF General Assembly 2003 in Winnipeg, Canada with the theme 'Healing of the World' - that the member churches had in an increasing way to grapple with controversial issues between their home countries and cultures and ethical approaches to worldwide challenges. This could only endanger the impact of the LWF's mission of reconciliation and unity. It needed a deeper spiritual foundation, and this he saw in the healing power of God.

\section{CRITICAL DIALOGUE ON ETHICAL ISSUES WITH CHURCH AND GOVERNMENT}

In the_earlier years of Buthelezi's theological wrestling on ethical questions, it was in view of the apartheid government and through his active roles in fighting for justice for voiceless people. Later on he wrote:

One of my concerns relates to our new democracy when it comes to moral issues and the role of the church in it. If the present trend continues, I am afraid, there is ultimately going to be a conflict between the state and the church. Yet the church, including its worldwide network, was one of the key midwives of our political liberation. The immorality of Apartheid was the chief entry point of the church's involvement...The influence which some of those political elements have exerted, has given rise to legislation and policies which have radical moral implications and which, to say the least, have put our nerves on edge. ${ }^{26}$

At the time of the Mbeki-government it was the controversy about the handling of the massive AIDS epidemic. At that time he battled on two frontiers: on the one hand the government did not want to admit the national health crisis in order not to harm the glorious vision of the 'African Renaissance'. This could not be tolerated by the church. But on the other hand clarity was necessary over against African traditional medicine to which many poor people took their refuge as the government hospitals only had limited means. Buthelezi took up the controversy with a government minister who would sit on TV talk-shows without a clear statement against the abuse of African traditional medicine in the time of AIDS.

I am not denying the existence of tradition(al) African herbs which are known to bring relief. What I have said should be understood in the context of the current controversy around AIDS and the new strains of TB... The goat industry (= traditional goat skin wrist bands) happens to be booming at the same rate as the frequency of deaths attributed or attributable to AIDS. ${ }^{27}$

25 M. Buthelezi, God's healing gift of Communion, Ezidwadweni 2003, p. 2.

26 Letter to E-A. Lüdemann, 20 April 2007.

27 Letter to E-A. Lüdemann, 15 January 2007. 
More intensively Buthelezi took up the matter of same-sex marriages which were legalised by the South African government (as the only one on the whole continent of Africa). In correspondence with a Zulu Member of Parliament he pointed to the dichotomy between the new Constitution of the country and the actual legal implications with regard to religious principles:

Our Constitution in its preamble invokes the name of God. It ends with the words "may God protect our people". How can God protect South Africa except through His laws? How can His laws do this if this country in its legislative processes does not take into account those laws as revealed not only in the Christian Bible, but also in the Scriptures of all religions and in the traditional customs of the indigenous peoples of Africa? ${ }^{28}$

But he is aware of the unresolved theological issue regarding this topic within his own church as much as in his church fellowship worldwide:

It is unfortunate that our partner churches in the North, particularly in Northern Europe, are so heavily lobbied and pressurised and intimidated by secular constituencies in their societies that they have lost faith in themselves and in the power of the gospel which has been entrusted to them and which they brought us in Africa. I am afraid that the gains of the ecumenical movement in healing doctrinal divisions around the question of salvation and related theological issues, are going to be undone by the current divisions around ethical questions like homosexuality, pornography and abortion on demand (in contrast to the therapeutic abortion). Churches in Africa which are the mission products of Protestant Europe are going to find themselves increasingly having more in common with the Roman Catholics than with their traditional partners. ${ }^{29}$

Here we witness the suffering in the mind and heart of a theologian who does not only construct systems of theological thinking but asks for the living expression of God's Word in his time.

\section{PERSONAL REFLECTIONS BY A COMPANION ALONG THE WAY}

In the year 2000 Bishop Buthelezi entered the time of his retirement and moved into the remote, but for the Buthelezi family traditional homestead at Ezidwadweni near Ceza in Zululand/KZN. But this did not at all mean that he removed himself entirely from the scene of his former activities. In his national church (ELCSA) and abroad (LWF) he was often invited to study conferences as well as for preaching and Bible weeks. In 2008 ELCSA sent him for a period of several months to Zambia in order to assist in the strengthening of a young Lutheran Church there. But even more than in the former years, he emphasised events which should open people for counting on the Holy Spirit in their life. On invitation of the LWF he took part in a worldwide

28 Letter to E-A. Lüdemann, 20 February 2007 (II) (in copy).

29 Letter to E-A. Lüdemann, 20 February 2007 (I). 
conference in Tanzania dealing with the reality of the Holy Spirit and of spiritual life in the church from the leadership to the local congregation. In 2003 he contributed amongst others to a meeting of the 'Spiritual Renewal of Congregational Life' (GGE) in the Evangelical Church in Germany (EKD) in Chemnitz. Back home he involved himself with various projects which combined the strengthening of spiritual life in the parishes and diaconic responsibility, particularly with the care of AIDS-affected children (Kenosis Diaconic Centre near Pietermaritzburg and plans for an extended diaconic centre together with a German Lutheran community of deaconesses near Ceza/KZN).

It would be rather worthwhile to look at the various distinct emphases during the life of Buthelezi and to ask what could be the link between them. The early impulse on his life was definitely the spiritual grounding in the ministry of his father and his paedagogical training in the Mariannhill institution in the ambit of the monastry. The intellectual hunger of this bright young person was then given room through the chances of international study and exchange on the basis of church relationships to Sweden and the USA. The other rather demanding burden on his life was added through the turmoil in his South African land of birth, which he as a mentally awake young person could not avoid but which he took up with great intensity in political involvement. And even when he had on the background of his earlier calling for the Christian ministry to take a clear decision for the way of the church, the commitment for a prophetic outreach into the fields of politics and social engagement for the community never lost his attention. As a theologian - of a rank which the Lutheran Church in southern Africa has so far not experienced again - Buthelezi had the important gift of relating his academic insights into the often confusing realities of the daily life in the parishes or the youth movements. One can even say that unsolved issues in the development of his church urged him to dive deeper into academic, but practically orientated questioning. And the older he became the more the spiritual experience of his early beginnings gained room in his intensive relationships to people along his way, Christian companions and beyond.

Buthelezi was a Christian with a rather wide range of thoughts and ambitions, but he realised that many of his wishes and longings in connection with his church could not be put into practice, nor could they be completed. What we experienced with him was how he held on to his faith and conviction that the Spirit of God would guide and mould him through the various challenges in this life - and so even in 'making him a bishop'. In the time of approaching old age when strength and mobility got more and more limited, he could still see one essential way forward in being a pastor and theologian, and this indicates a certain 'red line' running more and more obviously through a long life.

Sometimes when I reflect, new ideas and insights come to my mind. I used to ask myself: "What is the use of these personal insights since I am retired and can no longer share these insights with structured church groups?" I found a solution for myself. It occurred to me that 
the basic purpose of spiritual and theological reflection is the glorification of God. When we grow in knowing God and His things more and more, He becomes glorified in our lives (Phil. 3:10-11). ${ }^{30}$

\section{REFERENCES}

Becken, H.K. ed.. 1973. Relevant theology for Africa. Mapumulo.

Buthelezi, M. 2003. God's healing gift of Communion. Ezidwadweni.

Buthelezi, M. 2010. Profile of sociopolitical involvement. Ezidwadweni.

Buthelezi,M. 2010. The ordained ministry in the historical and ecumenical context' General Assembly Key-note, Johannesburg.

Cone, J.H. 1969. Black theology and black power. New York.

Hanssen, O. 1969. Theologiestudium in der Krise. Hermannsburg.

Mashabela, J. 2004. Manas Buthelezi. Dictionary of African Christian Biography. http://www. dacb.org/stories/southafrica/buthelezi_manas.html

\section{Correspondence}

Letter to E-A. Lüdemann, 15 January 2007.

Letter to E-A. Lüdemann, 20 February 2007(I).

Letter to E-A. Lüdemann, 20 February 2007 (II) (in copy).

Letter to E-A. Lüdemann, 20 April 2007.

Letter to E-A. Lüdemann, 30 June 2010.

Letter to E-A. Lüdemann, 4 April 2011.

30 Letter to E-A. Lüdemann, 20 February 2007(I). 